\title{
Africa's Industrialization Debate: A Critical Analysis
}

\author{
Mumo Nzau
}

\begin{abstract}
In the article, the author examines the debates that have permeated Africa's quest to catch-up with the more developed countries of the North. It is noteworthy that since independence, Africa's industrialization process seemed to be a state-centric affair. In other words, the state has been the central player in Africa's industrialization process. At independence, of course, many factors favored or called for state dominance as well as state-driven industrialization process. Yet a bad political culture, weak political and social institutions, poor leadership and bad governance seem to have contributed to this failure from within. However, the fact still remains that at the beginning of the $21^{\text {st }}$ century, African countries do hold a lot of potential in terms of human and material resources that would enable them compete favorably with the more industrialized countries of Europe, North America and Asia-Pacific.
\end{abstract}

External actors (the imperial power of Europe) were largely blamed for the historical underdevelopment of Africa. Further, the ideological divide that characterized the postSecond World era international system (1945-1990) may not have done any good to African development: Nuclear deterrence and the arms race of the Cold War fame; the wedge between the capitalist and socialist blocs, not only blurred Third World development but also bred many forms of poor governance especially in African countries- as super powers blatantly sought for ideological support from African Regimes and political elites without an iota of transparency and accountability. This state of affairs greatly retarded Africa's industrialization. This is because political populism and regime survival superseded economic development.

Nonetheless, it may not be wholly prudent for one to blame African woes on international politics. Indeed right from the 1960s African countries continued to receive colossal sums of money in the form of official development assistance (ODA); as well as grants and technical assistance from international financial institution (IFIs)- particularly the World Bank and the International Monetary Fund amongst other multilateral donor agencies. Similarly the same took place through bilateral donors, especially between leading super powers and former colonial powers in Africa. Two sets of arguments emerged from this state of affairs. The first argument was that African countries received donor funds and loans; and while a few exceptional ones used these funds for their intended used, others mismanaged them and this led to adverse economic effect in form of huge balance of payment deficits economic under-performance and of course a debt crisis.

The second argument takes the position that the donor agencies among other multilateral and bilateral arrangements are driven by all and/or insincere motives. While donor agencies purported to assist Africa's process of industrialization through financial, logistical and technical aid; in actual sense, it was only a scheme to produce jobs for 
westerners in the name of expatriates; to find market for their exports (imported by African states as capital goods) and to continue exploiting the African economy on behalf of western powers that essentially controlled them. The author examines the various models and debates that have shaped industrialization in Africa and the challenges at hand at the beginning of the $21^{\text {st }}$ century.

\section{Introduction}

Industrialization ${ }^{1}$ is a term that is mostly associated with the development experience of countries in Western Europe and North America during the $19^{\text {th }}$ and early $20^{\text {th }}$ centuries. In this early sense it referred to a marked departure from a subsistence economy that is largely agricultural towards a more mechanized system of production that entails more efficient and highly technical exploitation of natural resources in a highly formal and commercialized economic setting ${ }^{2}$. As such, industrialization was understood purely in economic terms particularly the physical presence of industrial plants that were involved in manufacturing capital goods as well as processing raw materials into finished goods either for further industrial use, general commercial use or purely for domestic use or purposes ${ }^{3}$. By the early $20^{\text {th }}$ Century therefore a country's industrialization was measured by the percentage of plants and/or industries involved in manufacturing as well as the volume of labour within such industries ${ }^{4}$. By around 1820, industrial activity had picked in Europe where coal was used run the steam engine among other industrial machines 5 .

To most western economists, especially classical economists of the Western tradition, the likes of Thomas Robert Malthus, Adam Smith, Ricardo, Keynes, believed that modern industrialization $^{6}$ was driven by several important components: capital, investments, surplus (savings) and technological advancement. These inter-connected variables were regarded as the most important ingredients that went to add value to land and labour in order for countries to build and sustain wealth ${ }^{7}$. It is this kind of thinking that drove western powers to explore other parts of the world in order to sustain the industrialization process back in their mother countries among other reasons ${ }^{8}$.

To the neo-classical and contemporary political economists of the western tradition, the industrialization experience of Western Europe and later North America during the $19^{\text {th }}$ and $20^{\text {th }}$ century can be understood as a unilinear process through which these societies

\footnotetext{
${ }^{1}$ Purma C. Samanta "What Helps or Hurts Industrialization: A Review from Economic History" in, Purna Samantra and Raj Kumar Sen Realizing African Development: A Millennial Analysis (CIIDS and IIDS, 2001), pp. 84-103

${ }^{2}$ John Rapley Understanding Development: Theory and Practice in the Third World (University, College London, 1997), pp27-53

${ }^{3}$ Michal P.Todaro Economic Development in the Third World (London, Longman, 1989), 62-85

${ }^{4}$ Colin Leys The Raise and Fall of Development Theory (Oxford, James Currey, 1996).

${ }^{5}$ UNCTAD African Development in a Comparative Perspective (Oxford, Janexs Currey, 1999).

${ }^{6}$ R. B. Sutcliffe Industry and Underdevelopment (Massachusetts Addison - Wesley Publishing Company 1971), pp. 16-103

7 Berman, Bruce J., editor, African Capitalists in African Development, (London, Lynne Reinner Publishers, 1994).

8 UNIDO 1969, "Small Scale Industry," Industrialization in Developing Countries: Problems and Prospects, UNIDO Monographs on Industrial Development, No. 11, UN, New York.
} 
evolved over a series of stages towards the ultimate state of industrialization ${ }^{9}$. One such scholar, Walt W. Rostow presented and supported this line of thought in his analysis of the industrialization experience in western society- this is what has come to be known as the Modernization Approach to development ${ }^{10}$.

Despite this term "industrialization" being solely associated with the Western development experience, political historians such as professor Ali Mazrui contend that other societies that date back several millennia, were themselves industrialized, modernized and modernizing but somewhere along the way this process was obliterated by historical accidents- natural or manmade. In other words the industrialization experience of the Old Chinese Empire, the Egyptian Kingdoms, and the Persian Kingdoms amongst other civilizations would pass to be modernization and "development" save for such historical accidents. The scholars who attempted to explain this state of affairs in political economy are known as the Neo-Marxists.

Neo-Marxists believe that the natural industrialization process of Africa (just as the rest of the Third World) was historically destroyed all together through slavery, colonization and neo-colonization. From the arguments of these two opposing schools of thought it is therefore clear that industrialization is a term that is relative depending on the tradition that informs those who conceive of it. Nonetheless, at the beginning of the $21^{\text {st }}$ century there is not much disagreement on what industry and industrialization is all about, but rather there is a lot of controversy as to how industrialization is to be arrived at or achieved. It is against this background therefore that the challenges of industrialization in Africa are to be analyzed.

\section{A Brief Historical Background of Industrialization in Africa}

Traditionally industrialization in its broad sense includes manufacturing, mining, construction and utilities such as electricity, water and gas among others. But further, the definition of industrialization during the latter years of the $20^{\text {th }}$ century expanded to refer to a process of development that is balanced and sustained as far as the economic as well as socio-political realms of any society are concerned ${ }^{11}$.

Colonial rule came to Africa as alien rule superimposed from outside mainly in the latter half of the $19^{\text {th }}$ century and established in the midst of on-going (perhaps what were naturally evolving) cultures. It was exercised either directly or indirectly by predominantly European administrators, colonial companies, among other imperial establishments and white settler populations $^{12}$. In the colonial economy the interest of the colonizing power and its local agents was to extract raw materials partly for purposes of feeding the industrial machine in Europe as well as raising revenue from the native populations, exploring markets for the products within the colonial economy and most

\footnotetext{
${ }^{9}$ Rostow, W. W. (1971). Politics and the Stages of Economic Growth, Cambridge: Cambridge University Press.

${ }^{10}$ Joan Edelman Spero The Politics of International Economic Relations (New York, St. Martins Press, 1990).

${ }^{11}$ V.A Oyenga "Industrial Versus Agricultural Development in Africa, in Contemporary Africa Monographs The challenge of development (E.A.E.P, 1968), pp.93-106

${ }^{12}$ Samir Amin, S. Imperialism and Unequal Development, (Sussex, England: The Harvester Press, 1977).
} 
importantly exploiting cheap labour for industrial purposes from the native population ${ }^{13}$. During the colonial era manufacturing in the continent was generally at the handicraft and small scale levels. In some colonies this was supplemented by some relatively complex industries producing mainly for export, but also producing for local consumption at the time focusing on food, fibre and wood processing and metal works in order to meet the needs fast growing urban populations ${ }^{14}$.

During the colonial era, natural resources were selected and exploited with a view to meeting the needs of the industries in Western Europe ${ }^{15}$. To this end, infrastructure, particularly all-weather roads and railroads were designed and built with the aim of facilitating the shipment of minerals and agricultural communities from the hinterland to the seaports for purposes of further shipment overseas. Other components of the colonial economy such as banking and communication were mainly established to facilitate this end $^{16}$.

At independence, the African economy inherited an industrial setting characterized by a traditional-modern dichotomy ${ }^{17}$. The traditional industrial setting is one that had been carried on from the pre-colonial times, survived the colonial economies and largely covered production and service activities related to basic household and agricultural needs at a traditional handicraft level by artisans- blacksmiths, porters, carpenters, carvers and weavers. This traditional industrial setting was practically based on human and animal power and used mainly local resources in addition to metal scrapes and wastes materials. On the other side of the dichotomy was the modern industrial setting which involved imported technology, machinery, equipment materials and production systems ${ }^{18}$.

\section{Industrialization Challenges that faced African countries in the early years of independence}

First and foremost, in the immediate post-independence period, African leaders differed on the strategy most likely to promote development in their countries. However, they agreed substantially over methods. The "instrument of both diagnosis and remedy was the development Plan"19. There were three options as far as development planning was concerned. The first one was the western model of development planning (also known as indicative) The western model allowed for the political economy to be shaped by market forces with limited state interference ${ }^{20}$. The second was the socialist style of development planning (also known as centralized or imperative planning). The third was a model that

\footnotetext{
${ }^{13}$ See also, Rodney, W. (1989). How Europe Underdeveloped Africa, Nairobi: Heinemann.

14 Turdoff William (2004) Government and politics in Africa (Houndmills, Basingtoke, London Macmillan).

${ }^{15}$ Ibid

${ }^{16}$ Ibid

${ }^{17}$ Ibid

${ }^{18} \mathrm{UN}, 1995$, World Economic and Social Survey 1995: Current Trends and Policies in the World Economy, (E/1995/50), New York.

19 Thomas J. Mboya "The Challenge of Development in Contemporary African Monographs, The Challenge Development (East Africa Foundation Publishers, 1968), pp .27-41

${ }^{20}$ Colon Legman Africa Since Independence_(Indianapolis, Indiana University Press, 1999).
} 
adopted what appeared like a merger of the capitalist and socialist models ${ }^{21}$. Thus, most countries chose to adopt centrally controlled development planning that was to operate within a mixed economy- one in which the public and private sectors played a substantial role. Some countries however chose to follow a purely socialist model in which the state controlled the economy in terms of who produces what and in what quantities. This was applied in countries like Tanzania, Mozambique and Guinea-Conakry.

At the same time, a second challenge faced by African leaders was the stark realities confronting their peoples in the immediate post-independence period: their peoples were faced with poverty, ignorance and disease. The great challenge posed therefore was one of uplifting the standards of life for their peoples through the provision of basic needs and the creation of a favorable environment by government- one that would engender economic growth and the creation of national wealth.

The third challenge was associated with the ideological path that was to guide the development process. African countries attained political independence at a time when the international political system was strongly shaped, conditioned and divided by the Cold War. They had to choose whether to adopt the socialist ideology or adopt the capitalist ideology or even declare their support for the non-aligned movement. Most African countries chose to be non-aligned and evolved their own ideological styles under the rubric of African socialism.

Fourthly, at independence African countries inherited an economy that was mostly not indigenous to them and at the same time this economy (almost in every sector was dominated by foreign companies or firms which had operated in the colonial economy). This meant that there was a very small domestic private sector of the indigenous kind. The local populations could not raise enough financial capital to support the economy. This small domestic industrial and financial base drove African governments to seek alternatives that took two forms. The first alternative was to set up state-owned and statecontrolled enterprises to run the economy- commonly known as parastatals. These parastatals (state enterprises) were supposed to jump-start industrialization in the newlyindependent countries for the good of all citizens. Such ventures included banking, transport and telecommunication manufacturing as well as marketing. The second option that was open to the African countries in their quest for industrialization was that of supplementing their fiscal budgets through economic aid and Official Development Assistance $^{22}$. This was done with a view to access the much needed foreign exchange, and further, with the aim of off-setting balance of payments deficits. African countries reached out to various bilateral and multilateral donors and lenders (World Bank, IMF among other International Financial Institutions).

Finally perhaps the greatest challenge to Africa's quest to industrialize in the early years of independence was purely political. This can otherwise be termed "the challenge of

\footnotetext{
${ }^{21}$ David Seddon and Dantel Seddon-Daines (Eds) A Political and Economic Dictionary of Africa_New York, Routeledge, 2005), pp.10-13

${ }^{22}$ Goran Hyden G. et al (eds.) Development Administration: The Kenyan Experience, (Nairobi: Oxford University Press, 1970).
} 
state formation". Whilst new states were formed at independence, the regimes that were in power got lured into the trap of popularizing and perpetuating themselves. At the same time these new forms of rulership adopted authoritarian styles or governance and soon towards- the late 1960s and early 1970s- most African countries were either faced with civil wars and rebellions, personal dictatorships and unconstitutional power take-overs through the barred of the gun. It may be observed therefore, that such challenges of the political kind were the most crucial in terms of either facilitating or spelling doom on the African quest for industrialization in the early years of independence ${ }^{23}$.

\section{Approaches to African Development}

In the early years of independence, the approach that was popular amongst developing countries (African included) was that of modernization. Modernization presented to Africa the thinking that the industrialization they were yearning for had already been achieved by the countries of North America and their former colonial powers in Western Europe $^{24}$. African countries did not need to "rediscover the wheel" but rather to follow an already set path towards industrialization; taking after the industrialized states of the North. This was to be realized through economic growth measured through indices such as the Gross National Product and annual economic growth rates ${ }^{25}$.

The other approach that was open for the African continent was that presented by the neo-Marxists. The Neo-Marxist approach ${ }^{26}$ (also known as the DependencyUnderdevelopment School) argued that the modernization approach was going to mislead the African process of industrialization because the historical experience of the Western economies took place under totally different circumstances. They further argued that the industrialization process in Western Europe and North America had itself interfered with the natural course of African's industrialization through slaverly, colonialism and neocolonial control. In other words African countries could never industrialize in a world economy that was already controlled by economic powers that historically underdeveloped them and one in which they were already inferior, dependent and unequal players ${ }^{27}$. The only option at hand for industrialization under such conditions was for African economies to disregard the modernization path and adopt the socialist path to industrialization ${ }^{28}$.

While these two approaches informed Africa's industrialization; consequently one either tried to find a middle ground between the two or an alternative all together ${ }^{29}$. Such are the

\footnotetext{
${ }^{23}$ Gromyko, Anatoly A., Editor, 1990, "Development of food production and distribution in the Agrarian Sector." Agenda for Action: African-Soviet - Cooperation, Lynne Reinner Publishers, London.

24 Baker.C.R., Bhagavan, M.R., Mitschoke-Collande, P.V. and Wield, D.V., 1986, African Industrialization, Gower Publishing Company Limited, Aldershot.

${ }^{25}$ J.C.N Osogo Kenya's World of Commerce and Industry (Nairobi 1970), pp.17-27

${ }^{26}$ Charles Wilber (editor) The Political Economy of Development and underdevelopment (New York, RandomHorse1973), pp.65- 114. See also, Rodney, W. (1989). How Europe Underdeveloped Africa, Nairobi: Heinemann.

${ }^{27}$ Andre Gunder Frank, Dependence Accumulation and Underdevelopment, (New York: Monthly Review Press, 1972)

${ }^{28}$ Nigel Harris, 1986, The End of the Third World, (UK, I.B. Tauris and Co. Ltd., 1986).

${ }^{29}$ Dwevidi and Neff (1982) "Crises and Continuities in Development Theory and Administration: First and Third World Perspectives" Administration and Development, Vol. 2 (1)
} 
liberal and populist approaches. Such models were keen to point out that both the modernization and dependency paradigms were not tackling the actual problems hindering African development. Instead they looked at industrialization from the realities facing African populations and; what they could do at the village level as well as within the informal sector engender economic growth and wealth creation. These included the problems of rural poverty and urban destitution, food insecurity, illiteracy and malnutrition among others.

\section{Industrialization Models in Africa, 1960s-1990s}

A model is a guide to implementation. It sets forth the parameters- the means and the ends to be met. In the post-independence period, African countries adopted several models of industrialization. The first was that of import-substitution model (ISI) ${ }^{30}$. It was prevalent in the 1960 s to the 1970 s. The second model was one that was associated mainly with rural development activities. This was the integrated rural development model (RRD). This model was prevalent to the 1970s and $1980 \mathrm{~s}^{31}$. The third and most recent was that of structural adjustment (SAPs). It was prevalent in the mid 1980s all the way to the 1990 's ${ }^{32}$.

Import substitution can ideally be accomplished in three phases ${ }^{33}$. The first is done by locally producing the same previously imported goods such as pharmaceuticals, agricultural equipment and machinery using imported finished materials and fabricated paths and components. This involves final stages of processing and assembly into finished goods consumed goods ${ }^{34}$. The second phase can be considered a continuation of the first phase but one that progressively decreases the import contents of domestic manufacture- thereby upgrading the first phase to incorporate locally-made materials parts and components ${ }^{35}$. The third phase entails replacing the imported goods altogether by the same or alternative goods made locally for basic indigenous raw materials and these include agricultural equipment and other machinery made of metals extracted from ores $^{36}$. The import substitution strategy was basically an inward looking strategy and it was regarded by many African countries not only as an end but also a means to higher level of industrial development on the African continent ${ }^{37}$. It was expected to facilitate industrial development by enabling the countries to acquire and familiarize themselves with industries and technology- thus providing jobs and creating wealth for the

30 Peter Angang' Nyango "The Posibilities and Historical Limitations of Import- Substitution Industrialization Kenya" In Peter Coughli and Gernshon Ikiara Industrialization in Kenya: In Search of a Strategy_(London, James Canney 1998), pp 6-51

${ }^{31}$ P.Ndegwa, L.P Mureithi and R.H. Green_Development Options for Africa: In the 1980s and Beyond (Nairobi, Oxford University Press, 1985) pp. 17-27

32 Charles Harvey, Editor, Constraints on the Success of Structural Adjustment Programmes in Africa (London, Macmillan, 1996).

${ }^{33}$ ECA 1996, Africa in the 1990's and beyond: ECA-Revised long term development Perspectives Study (ECA/SERPD/TP/96/3), Addis Ababa

${ }^{34}$, Smail Khennas (ed.), Industrialization, Mineral Resource and Energy in Africa, (CODESRIA, CODESRIA Book Series, Rowe, Oxford, 1992)

${ }^{35}$ Riddel, Roger C., Manufacturing Africa, (Portsmouth, Heinmann Educational Books Inc, 1990).

${ }^{36}$ Robert B. Reich, The Work of Nations, (London, Simon \& Schuster, 1991).

${ }^{37}$ Singer, Hans, 1977, Technologies for Basic Needs (Geneva, ILO, 1977) 
countries $^{38}$. It was intended to lead progressively to the manufacture of capital goods. Industrialization using this model however did not come true for most countries ${ }^{39}$. One of the most outstanding drawbacks was that associated with the oil crisis of the 1970s. African countries found that they were paying hefty prices for oil and this tremendously slowed down the import substitution model ${ }^{40}$.

In the late 1960s, African countries realized that the modernization approach to development was not providing all the answers in their quest to industrialize. This reality was confirmed by leading international financial institutions including the World Bank (IBRD) as well as the International Monetary Fund (IMF) ${ }^{41}$. The Integrated Rural Development model was informed by two major premises. First, while many African countries recorded high economic growth rates, most of the populations remained poor and underdeveloped and characterized by "an economy of affection"- a rural peasantry operating within an informal economy. Secondly, international financial institutions and multilateral donors realized that most of the African economies were dual with a large percentage of the impoverished population depending on small-scale agriculture within a rural setting. In this sense therefore, African industrialization needed to be re-thought, hence the need for alternative approaches ${ }^{42}$.

The IRD strategy earned this tag "integrated" due to the fact that it was a combination of various approaches; namely the basic needs strategy (BNS), the special ruraldevelopment programmed (SRDP) and variants of it such as the District Focus for Rural Development that was applied in Kenya. Among these the most outstanding was the basic needs strategy which sought to balance the purely economic indicators of growth with the social realties of poverty and inequality ${ }^{43}$. In 1973, Robert McNamara (A senior World Bank representative; in a speech made in Nairobi) brought to the attention of the world the poverty facing the people of Africa and the rest of the Third World in a global economy that was dominated by few rich western Countries. The basic needs strategy therefore was meant to attack rural poverty by addressing basic needs in order to raise the living standards of the rural poor in addition to commercializing agriculture ${ }^{44}$.

In general, the integrated rural development model aimed at addressing the problems of rural poverty or integrating the informal small-scale rural agricultural industry into the mainstream economy thereby adding value to the process of industrialization ${ }^{45}$. However

\footnotetext{
${ }^{38}$ Meier. Gerald M. and William F. Steel, eds., Industrial Adjustment in sub-Saharan Africa, EDI series in Economic Development, (New York, Published for the World Bank, Oxford University Press, 1989)

39 Peter Anyang' Nyongo "The Posibilities and Historical Limitations of Import- Substitution Industrialization Kenya" In Peter Coughli and Gernshon Ikiara Industrialization in Kenya: In Search of a Strategy_(London, James Canney 1998), pp 6-51

${ }^{40}$ Ibid

${ }^{41}$ UNIDO, "Small Scale Industry," Industrialization in Developing Countries: Problems and Prospects, (New York, UNIDO Monographs on Industrial Development, No. 11, UN, 1969).

${ }^{42}$ Chambers, R. (1974). Managing Rural Development: Ideas and Experience from East Africa, Uppsala: The Scandinavian Institute of African Studies.

${ }^{43}$ Victor Ayeni (ed), Public Sector Reforms in Developing Countries (London, Commonwealth Secretariat, 2002).

${ }^{44}$ William Tordoff Government and Politics in Africa (New York, Macmilan, 2004).

${ }^{45}$ Alex Thomson An Introduction to African Politics (London, Macmillan, 2003).
} 
the sad reality was that apart form this model being poorly-implemented as well as poorly-interpreted by African governments, many other intervening factors such as lack of capital, lack of commitment by governments, poor infrastructure and unstable international markets for agricultural products ${ }^{46}$, international financial institutions such as the World Bank did not work hard enough to ensure the ultimate realization of the IRD $\operatorname{model}^{47}$.

In the late 1970s, it was realized that state-driven development in the Third World countries was failing to meet its original objectives. African governments had sought to initiate industrial growth through the parastatals ${ }^{48}$. To finance and equip these ventures, African governments borrowed heavily externally especially from the Breton Woods institutions, the World Bank and the IMF.

Unfortunately, such public ventures in the form of public enterprises, public limited companies as well as quasi-governmental agencies performed dismally. This dismal performance could have been due to varied factors. One outstanding reason why public enterprises underperformed is associated with political interference ${ }^{49}$. It so happened that in the 1960s many governments around Africa were faced with the challenges of state formation and political survival. For these reasons such public enterprises were used as bait to secure strategic and political support for incumbent regimes; through jobs and monetary rewards from these enterprises/parastatals ${ }^{50}$. This opened up fertile ground for corruption, misappropriation of funds, nepotism, fraud and favoritism on ethnic lines, which led to collapse of such enterprises. The World Bank and IMF on either part, along side other bilateral and multilateral donors, felt that that it was high time the strategies to African development and industrialization were re-considered and re-oriented to the realities in African countries ${ }^{51}$.

It is against this background that they introduced the idea of structural adjustment programmes (SAPs). SAPs were designed to reduce the role of government in the industrialization process. It was believed that the public service and the public sector in general could not deliver industrialization because of bad politics which led to mismanagement and which further and stifled industrial growth ${ }^{52}$. In other words, the public sector in Africa was "too large" and that it was high time the African economies were opened up to market forces. Structural adjustment therefore was a process of the 1980s that attempted to reduce the role of government in industrialization and through

\footnotetext{
${ }^{46}$ Richard Sandbrook Politics of Africa's Economic Recovery (1999)

${ }^{47}$ Ladipo Admolekun Ladipo Public Administration in Africa: Main Issues and Selected Country Studies (Oxford, West view Press, 1999).

${ }^{48}$ Rondinelli D.A. Development Projects as Policy Experiments: An Adaptive Approach to Development Administration (London, Routledge).

49 Ibid

50 Ibid

51 Ibid

52 Ibid
} 
economic liberalization and what later in the early 1990s, came to be known as political accountability, transparency and better governance ${ }^{53}$.

Nonetheless, several alternatives strategies were proposed as far as African Industrialization is concerned. One is the Export-Oriented Industrialization ${ }^{54}$. During the post-independence period, most African primary communities were exported in crude or semi-processed form. Many African countries exported five main types of goods in the 1970s: Processed primary products e.g. vegetable oil, food stuffs, pulp; Non-traditional labor-intensive goods-glass ware, pottery, wigs, plastic and wooden items; Traditional labor-intensive goods - textile, garments, footwear etc.; Products and assemblies, manufactured by multinational corporations- semi conductors, television tubes and values (electronics in general, and; Manufactured goods which may have started off originally as import substitutes e.g. car parts, cables, bicycles, electric motors etc ${ }^{55}$. In general, only a limited number of countries have benefited from export of the processed and manufactured goods. The other challenge with the export-oriented model is that most African countries continued to face stiff competition from such activity from Asia and Latin America exporters - meaning that African countries were late-comers as far as the export strategy is concerned- perhaps because of over indulgence in the import substitution model (ISI) ${ }^{56}$.

The other alternative model has been identified as the Industrializing-Industries Model. With the passage of time the limitations of the ISI model became apparent. In the real sense of the word; a country cannot and should not depend almost exclusively on imported inputs. First, this would be "putting one's eggs in one basket" meaning, experience with one model ${ }^{57}$. Secondly it called for increased foreign exchange revenue in order to purchase capital goods ${ }^{58}$. Thirdly, it was also tantamount to giving up exploiting one's own resources. The alternative to all these was the industrializing industries model which literally meant establishing industries that produced intermediate inputs for other industries; they comprise metals and chemicals and engineering industries; for example, they produce metal and chemicals needed to make capital goods required by all industries and other economic and social activities ${ }^{59}$. Unfortunately, very few African economies have proven to have the capacity ${ }^{60}$.

\footnotetext{
${ }^{53}$ Makonnen Alemayehu Industrializing Africa: Development Options and Challenges for the $21^{\text {st }}$ Century (New Jersey, 1999), pp. 114-121.

54 Ibid

55 Ibid

56 Ibid

${ }^{57}$ ECA 1990, Directory of Project Profiles on Institutional Support for small scale Industries, (Addis Ababa, ECA/IHSD/SSI/009/90, 1990).

${ }^{58}$ World Bank. 1992, Proceedings of the World Bank: Annual Conference on Development Economics 1992. See also, World Bank, 1997, World Resources 1996-97, Washington D.C. World Bank, 1997, World Resources 1996-97, Washington D.C.; World Bank. 1992, Proceedings of the World Bank: Annual Conference on Development Economics 1992.

${ }^{59}$ UNIDO Industrial Development Report_(UNIDO, Global Report 1996).

${ }^{60}$ Roger Fiddel etal Manufacturing Africa: Performance and Prospects of Seven Countries in Sub-Saharan Africa (Portsmouth Heinemann, 1990), pp. 10-58
} 


\section{Factors Impeding Industrialization in Africa since the early 1990s}

As was discussed earlier in the paper, the 1970s and 1980s was African countries seeking to industrialize using various models. However, as the 1980s faded away and the 1990s set-in, the African industrialization process experienced fresh challenges, that acted rather negatively in shaping the industrialization process ${ }^{61}$. Earlier in the decade of 1970s and 1980s African countries sought to borrow from various bilateral and multilateral donors in order to finance wealth creation and/or to jump-start the industrialization process. It so happened that African economies accumulated a lot of debt to the tune of tens of billions of dollars $^{62}$. It is in mid 1980s that the reality started to dawn on African countries that they were spending much more on servicing foreign loans than for their domestic growth. It is this state of affairs that in that came to be known as the Africa debt crisis ${ }^{63}$. An indebted country cannot industrialize since most of its GDP/GNP proceeds go to servicing foreign debt. In essence therefore the African debt crisis was identified as a major impeding factor to the industrialization process in Africa ${ }^{64}$.

As such, these countries suffered huge balance of payments deficits. This meant that they lacked international hard currencies that were vital for the importation of capital goods which were necessary for the manufacturing and processing industries. As a result of this state of affairs, many African countries lacked the capacity to exploit the necessary natural resources for manufacturing purposes; in addition to the relevant technology ${ }^{65}$, as well as liquid capital that is needed to sustain this process. This forced them to be dependent on more developed countries for capital goods, industrial inputs technology and liquid capital. This weak capital base of African countries has acted as a major impeding factor to the industrialization process in the last decade ${ }^{66}$.

The end of the Cold War ushered in a new era in which, incumbent forms of poor governance could not be sustained. As early as 1990 many African governments were faced with armed rebellions which lead to the deposition of long serving personal dictatorial regimes in countries like Ethiopia, Liberia, Somalia, Sudan, Rwanda and the former Zaire (DRC Congo) ${ }^{67}$. At the same time, former single-party systems were swiftly replaced by multiparty systems in countries such as Kenya, Tanzania, Zambia, Uganda and Malawi yet despite these regime changes and the re-adjustments in the African body politic, the African state continued to suffer a crisis of legitimacy with multi-partism failing to deliver "the democratization dream" 68 . At the same time, armed rebellions ignited outright civil war; total destruction, wanton human suffering, genocide and

\footnotetext{
${ }^{61}$ Roy Cole and H.J De Blij A Survey of Sub-Saharan Africa_(New York Oxford University Press, 2007).

${ }^{62}$ African Forum on Strategic Thinking: Towards the Earth Summit and Beyond Sustainable Development Governance and Globalization (Nairobi, Hennich Boll Foundation, 2001).

${ }^{63}$ Michael Braff Brown Africa Choices: After Thirty Years of the World Bank (Boulder, West view Press, 1995), pp. 1-13, pp. 13-29, pp. 29-50; pp. 50-65; pp. 65-83; pp. 83-100, pp 135-154.

${ }^{64}$ Stephen Fellis (Editor) Africa Now: People, Policies and Institutions London, James Carrey, 1996), pp $155-174$

65 Sola Ankrinade and Amadu Sessay (Editor) Africa in the Post-Cold War International System (Washington Printer, 1998),pp. 3- 28

${ }^{66}$ Ian Jaylor and Paul Williams (Editor) Africa in International Politics: External Involvement in the Continent (London, Roundledge,2004), pp 174-194

${ }^{67}$ Vijay Gupta Africa : Post Cold War Era (New Delhi, Har-Anand Publications, 1996), pp. 1-13

${ }^{68}$ Peter Sehweb Africa: A continent self-Destruct_(New York, Palquave, 2001).
} 
regime collapse in countries like Burundi, Rwanda, Sierra Leone, Liberia, Somalia and more recently, the Western Darfur region of the Sudan. Those political maladies facing the African state have acted as the major impediments to industrialization on the continent $^{69}$.

In another line of argument, it may be observed that for most of Africa's postindependence period, the continent in general appeared to be a late-comer as well as an inferior actor in the international political economy ${ }^{70}$. One area of weakness is the continent's inability to play a leading role as far as international trade and international trading regimes is concerned ${ }^{71}$. Throughout the $1960 \mathrm{~s}$ through to the $1990 \mathrm{~s}$, the international trading system was under the control of the developed countries of the North under the General Agreement on tariffs and Trade (GATT) arrangement ${ }^{72}$. This system generally failed to treat African countries as equal players in the international trading system. In the same token, the World Trade Organization (WTO), which was formed in 1994 to replace the GATT, also failed to create a favourable environment as far as the place of Africa and the rest of the Third World is concerned. International market shocks, as well as an international trade regime beyond Africa's control have continued to act as a major setback to Africa's industrialization process ${ }^{73}$.

But Africa's industrialization woes cannot entirely be blamed on the North. African regional integration seemed compromised right from the start. The OAU Charter of May 1963 was itself a compromise arrangement ${ }^{74}$. A group of African leaders led by Kwame Nkrumah, Julius Nyerere and Sekou Toure of Guinea wished that Africa would be united as one country- The United States of Africa. However, the majority of leaders preferred the formation of sub-regional groupings which would, over time, pursue the dream of a united Africa ${ }^{75}$. On a critical note, most of these sub-regional groupings; the East African Community (EAC), the Economic Community of West African States (ECOWAS), the Southern African Development Coordination Conference (SADCC), the Magrheb Group among others; did not manage to deliver the Pan-African dream let alone secure any formidable development among the member states. Also most of these groupings were not created purposely of economic reasons. In fact, amongst the earlier ones, only the

\footnotetext{
${ }^{69}$ See also, "Inter-African Diplomacy and the Crises of the Post Cold War Period" in East African Journal of Humanities and Sciences (CUEA Press, 2007).

${ }^{70}$ ECA 1996, Africa in the 1990's and beyond: ECA- Revised long term development Perspectives Study (ECA/SERPD/TP/96/3), Addis Ababa.

${ }^{71}$ Onwuka, R. I. and A. Sesay (eds.) The Future of Regionalism in Africa (Nairobi: Academy of Science Publishers, 1990).

${ }^{72}$ Nyongo, P.A., (ed) Regional Integration in Africa: Unfinished Agenda. (Nairobi: Academy of Science Publishers, 1990).

${ }^{73}$ Bach, D.C. (1998). "New regionalism as an alias: Regionalization through trans-state networks". In J. Andrew Grant and Fredrick Söderbaum (ed.), The regionalism in Africa. London: Ashgate. pp. 21-30.

${ }^{74}$ ECA/UNIDO, 1995, Report on regional strategy for Rational Location of Industries in the Context of the Abuja Treaty (CAMI.12/6[a]), Addis Ababa.

75 F. Carmignani, F. The road to regional integration in Africa: Macroeconomic convergence and performance in COMESA. Journal of African Economics, Vol. 15, No. 2 (June 2006), pp. 212-250.
} 
Economic Community of West African States (ECOWAS) stood out as a pure economic sub-regional grouping ${ }^{76}$.

In recent years, some of these organizations have evolved economic integration policies which sought to boost industrialization among member states through common policies in customs and excise, fiscal planning, regional development, trade and industry, central banking and immigration ${ }^{77}$. Despite such moves, these organizations have been unable to engender industrial growth among African countries, to the point of being formidable actors and competitions in the international economy. Several factors can be identified to account for this state of affairs ${ }^{78}$.

First, individual African countries within these regional economic blocs seemed to pursue varied and sometimes conflicting industrial strategies. Secondly, these countries also seemed to pursue different political ideologies ${ }^{79}$. This was the problem that faced the EAC between 1967 and 1977 particularly between Kenya and Tanzania. Tanzania seemed to follow the socialist ideology while Kenya seemed to pursue the capitalist ideology. The same applied to many other countries, in North Africa, West Africa and Southern Africa. These ideological differences would at times lead to inter-state conflict and these would further weaken sub-regional economic groupings capacity to facilitate industrialization among member countries ${ }^{80}$.

Over the years some countries tended to have membership in more than one economic grouping. A country may be a member of EAC, SADCC, and COMESA all at once thereby blurring the effectiveness and vision of such groupings as far as the industrialization process is concerned. All these factors put together have left regional economic groupings in Africa being mere talk shows which are grossly under-funded and therefore unable to compete with others around the world such as the European Union, Association of South, East Asia Nations (ASEAN) the North Atlantic Free Trade Area (NAFTA) and the Organization of American States (OAS), among others.

It may be recalled that as the 1980 s began African countries entered the Third Development Decade without much progress towards achieving their common goals. It was against this background that the Assembly of Heads of State and Government of the Organization of African Unity (OAU) adopted the Monrovia Declaration in late 1979. It was the Monrovia Declaration that gave rise to the strategy of self-reliant African development in 1980- the Lagos Plan of Action (LPA) ${ }^{81}$.

\footnotetext{
${ }^{76}$ Apter E. David and Roseberg G. Carl (1994) Political Development and the New Realism in SubSaharan Africa (Charlottesville and London: University press of Virginia).

${ }_{77}^{7 n}$ Onwuka, R. I. and A. Sesay (eds.) The Future of Regionalism in Africa (Nairobi: Academy of Science Publishers, 1990).

${ }^{78}$ Ibid

${ }^{79}$ Ibid

${ }^{80}$ East African Community.. EAC Update. Prepared by; Magaga Alot, Information and Public Relations Officer. Arusha: EAC Secretariat. (2006, September)

${ }^{81}$ S.K.B Asante African Development: Adebayo Adedoji's Alternative Strategies (Melboume Hans Zell Publishers 1991) pp.36-78
} 
The Lagos Plan of Action was a Blue Print for African development and industrialization that stressed on the importance of African initiatives in the process ${ }^{82}$. The LPA (Lagos Plan of Action) was a product of regional integration initiative namely the United Nations Economic Commissions for Africa and the OAU. More specifically the LPA set fourth self-sufficiency, self reliant industry, transport and communication, human and natural resources, science and technology as the main premises for African development. At the same time African Finance Ministers under the umbrella of OAU requested the World Bank to prepare a Special Report on the way forward as far as African development was concerned $^{83}$.

The World Bank on its part prepared the report entitled, "Accelerated Development in Sub-Saharan Africa: An Agenda for Action" in 1981. This report was commonly known as the Berg Report ${ }^{84}$. The Berg Report stated that it reaffirmed the long term objectives on African development as expressed in the Lagos Plan of Action. However, it foresaw the need for alternative short-term and medium-term actions to respond to Africa's economic difficulties. According to this Report, the World Bank believed that Africa still needed financial aid to stimulate a renewal of economic growth ${ }^{85}$. The central theme of the Berg Report stressed that more efficient use of scarce resources- human and capital, managerial and foreign- were essential for improving economic performance in most African countries in order for them to industrialize. The report also emphasized the interdependence of countries in the world economy and that Africa could not ignore this fact $^{86}$.

In accordance with these realities, African countries were advised to pursue "their comparative advantage" by striving to improve production of their export products. This was in contradiction to the Lagos Plan of Action in that, it was encouraging African countries to continue exporting primary products such as coffee, tea and cocoa and reliance on foreign exchange earnings in order to afford essential manufactured goods through importation ${ }^{87}$. Most African governments were against these recommendations because they believed such a path would aggravate their economic problems and/or put African countries in a permanent sate of dependency- thereby drawing back its industrialization $^{88}$.

As far as the Lagos Plan of Action was concerned, three major considerations seemed to favor its disengagement strategy: first, economic, relations with the more advanced

${ }^{82}$ UNIDO/ECA, Alliance for Africa's Industrialization, Thirteenth Meeting of the Conference of African Ministers of Industry (CAMI.13/5, 1997),Accra.

${ }^{83}$ OAU. 1981, Lagos Plan of Action for the Development of Africa, International Institute for Labour Studies. Geneva.

${ }^{84} \mathrm{UN}$, A Programme for the Industrial Development Decade for Africa, (New York, UN, 1982).

${ }^{85}$ E.S. Otieno Odhiambo "Africa's Place in the World Dialogue at the Beginning of the Twenty-First Century, in P.G. Okoth Africa at the Beginning of the $21^{\text {st }}$ Century (Nairobi, Nairobi University Press, 2000), pp.213-227.

${ }^{86}$ Maurice Amutabi "Globalization an the Politics of GNP and GDP in the Twenty-First Century Africa" in in P.G. Okoth Africa at the Beginning of the $21^{\text {st }}$ Century (Nairobi, Nairobi University Press, 2000), pp.269-286.

${ }^{87}$ Ibid

${ }^{88}$ Ibid 
economies of the North (the centre) tended to produce undesirable economic distortations that disfavoured Africa's quest to industrialize ${ }^{89}$. Secondly, economic exchanges between the Centre and the Periphery were traditionally characterized by inequality and were thus harmful to African industrialization. Thirdly, the experience in other parts of the Third World was that, meaningful industrial development was realized only if it was preceded by disengagement from the influence of the more developed economies of the countries of the North. Proponents argued that self-reliance is attained by reducing economic dealings with the Centre, reorientation of trade ties towards the economies of the Periphery and simultaneous implementation of self- reliance by a number of similar countries in the Periphery ${ }^{90}$.

The LPA, and its strategy of self-reliance, was significant in several ways. First it reflected a growing awareness among African leaders of Africa's acute socio-economic problems particularly its underdevelopment, poverty and inequality ${ }^{91}$. Secondly, it demonstrated that African leaders recognized the need to co-ordinate economic policies and actions at the regional and sub-regional level. Third, it seemed to recognize the failure of conventional development strategies in Africa. It was therefore seeking to rejuvenate the role of the state and state related institutions- the general public sector- in the industrialization process and development in general $^{92}$.

Towards the end of the decade of the 1990s, otherwise known as Africa's Fourth Development Decade; African statesmen and general academia expressed the feeling that African regionalism and sub-regional economic integration under the umbrella of organization of African Unity (OAU) had largely failed to deliver the industrialization dream for Africa ${ }^{93}$. In fact, the African industrialization process seemed more reliant more than ever before on financial aid as well as the importation of capital goods; while at the same time being conditioned by the World Bank and other international financial institutions ${ }^{94}$.

The 1990s hence presented Africa as a continent in crisis as many countries around the continent suffered civil wars, regime collapse, drought and widespread food insecurity. The industrialization plans of yesteryears under regional economic integration were reduced to mere pipe dreams ${ }^{95}$. With the end of the Cold War, a more powerful World Bank and IMF, a new and highly western controlled international trade regime under the World Trade Organization (WTO) and a new era of western oriented neo-liberalism

\footnotetext{
${ }^{89}$ Ibid

${ }^{90}$ UN, Regional Cooperation: Second Industrial Development for Africa - Note by the Secretary GeneralAddendum: Programme for the Second Industrial Development Decade for Africa (1991-2000), E/1992/14/Add.1 (Part II), New York, 1992.

${ }^{91}$ UNDP, 1996, Human Development Report 1996, (New York, Oxford University Press, 1996)

92 P.G. Okoth "The Changing Realities of Africa at the Beginning of the $21^{\text {st }}$ Century" in, P.G. Okoth Africa at the Beginning of the $21^{\text {st }}$ Century (Nairobi, Nairobi University Press, 2000), pp.367-389.

${ }^{93}$ United Nations Economic Commission for Africa Transforming Africa's Economics (Addis Ababa UNCA, 2001), pp. 18-28)

${ }^{94}$ World Bank Sub-Saharan Africa: From crisis to sustainable Growth. (Washington, World Bank, 1989).

${ }^{95}$ “'G.P Okoth Africa at the Beginning of the $21^{\text {st }}$ Century (Nairobi, Nairobi University Press, 2000), pp.213227
} 
encapsulated in the term "Globalization" came to the fore. It was under these circumstances that African leaders heavily criticized the OAU and proposed the African Union (AU). In the OAU Summit held in Lome, Togo in July 2000, the leaders sought to transform the OAU into an organization modeled on the European Union (EU) ${ }^{96}$.

Since 2001, the AU sought to rejuvenate Africa's industrialization though a number of initiatives the most outstanding was the New Partnership for Africa's Development otherwise known as (NEPAD) can be termed as Blue Print for African development and industrialization $^{97}$. NEPAD is a product of the Millennium Partnership for the Africa Recovery Programme (MAP) and the OMEGA Plan. The African Unions Institutions framework is the implementation vehicle for the plan while NEPAD's heads of state are required to report to the AU annually ${ }^{98}$. NEPAD was initially known as New African Initiative (NAI). NEPAD was adopted as Africans principle Plan for development providing an integrated comprehensive framework for socio-economic development. It appeared as though NEPAD was open to combine the African-bred industrialization initiative on one hand and the realities in the international political economy at the beginning of the $21^{\text {st }}$ century ${ }^{99}$.

This meant that NEPAD sought to promote accelerated and sustainable development through eradication of widespread and severe poverty while at the same time arresting what appears to be Africa's marginalization in the globalization debate ${ }^{100}$. Another important feature which seemed to be an internal check on African development and governance initiatives is the Africa Peer Review Mechanism (APRM) which, all African Union members are expected to participate in the APRM requires each country to perform a self evaluation in areas of democracy governance and socio-economic development ${ }^{101}$.

\section{Conclusion: Future Prospects for African Industrialization in a Globalizing World}

Globalization is not a very recent phenomenon as contemporary literature presents it to be. Over the centuries, particularly in the post renaissance period; countries and regions around the world continued to influence each other politically, culturally, socially and economically ${ }^{102}$. Nonetheless, in its recent usage, the term has been applied to refer to a wave of change; the beginning of which was marked by the end of the Cold War thereby opening the new era of global inter-relationships characterized by advanced

\footnotetext{
${ }^{96}$ World Bank Can Africa Claim the $21^{\text {st }}$ Century? (Washington DC, World Bank, 2000), pp.210-219

${ }^{97}$ Timothy Muriithi The African Union : Pan-Africanism Peace Building and Development_( Burlington, Ashgate Publishing Coupary, 2005), pp. 137-169

${ }^{98}$ Gordon Cumming Aid to Africa: French and British Policies from the Cold War to the New Millennium (London, Ashgate, 2001).

${ }^{99}$ Henning Nelber et al The Partnership for Africa's Development (NEPAD) -Africa Perspectives_(Uppsala, Nordiska Afrika Institutet, 2002), pp 1-33.

${ }^{100}$ David K. Leonard and Scott Straves Africa's Stalled Development: Internal Cares and Cures (Boulder, Lyme Premier Publishers, 2003)

${ }^{101}$ Fanta Cheru African Renaisance: Roadmaps to The Challenge of Globalization (London, Zed Books 2002), pp. 1-32

${ }^{102}$ Eric Masinde Aseba Africa in the $21^{\text {st }}$ Century (Eldoret, Zapf Chancery, 1996), pp.29-37
} 
telecommunication, air and sea transport, and technology ${ }^{103}$. It is characterized by a digital age which has made global financial transactions faster and far much efficient.

It has been observed that the globalization debate is associated with American and/or Western-led neo-liberalism ${ }^{104}$. With the end of the Cold War, it appeared that the Western economic order had emerged supreme and it continued to use the globalization agenda as a way of accessing markets and economic control particularly among the countries of the Third World ${ }^{105}$. For Africa, like the rest of the Third World, globalization and all its attendant processes may be nothing but a mere conduit for further domination of the world economy by the developed countries of the North. Nonetheless, many quotas around Africa have expressed the contention that globalization presents the greatest opportunity for African countries to industrialize through the wealth of investment opportunities it creates- markets, more efficient access to advanced technology and international capital flow ${ }^{106}$. In this light, globalization is viewed either as a catalyst or an impediment to Africa's industrialization depending on the premise taken by those who support or criticize it. It is up to the continent to make the best of the situation.

\section{References}

African Forum on Strategic Thinking: Towards the Earth Summit and Beyond Sustainable Development Governance and Globalization (Nairobi, Hennich Boll Foundation, 2001).

Baker.C.R., Bhagavan, M.R., Mitschoke-Collande, P.V. and Wield, D.V., 1986, African Industrialization, Gower Publishing Company Limited, Aldershot.

Berman, Bruce J., editor, 1994, African Capitalists in African Development, Lynne Reinner Publishers, London

Charles Harvey, Editor, Constraints on the Success of Structural Adjustment Programmes in Africa (London, Macmillan, 1996).

Charles Wilber (editor) The Political Economy of Development and underdevelopment (New York, RandomHorse1973), pp.65- 114

Claude Ake A Political Economy of Africa, (London: Longman,1981)

Colin Leys The Raise and Fall of Development Theory_(Oxford, James Currey, 1996).

Colon Legman Africa Since Independence_(Indianapolis, Indiana University Press, 1999),

David K. Leonard and Scott Straves Africa's Stalled Development: Internal Cares and Cures (Boulder, Lyme Premier Publishers, 2003)

David Seddon and Dantel Seddon - Daines (Eds) A Political and Economic Dictionary of Africa_New York, Routeledge, 2005), pp.10-13

\footnotetext{
${ }^{103}$ Musa I.M Abutundu "Reflections on Early $21{ }^{\text {st }}$ Century Africa "In Olugbenga Adesida and Annual Otch (Editor) Africa Volces and African Visitors (Stockholm, Elanders Gotab, 2004), pp. 19-30

${ }^{104}$ P.S Okoth "The changing Realities of Africa at the Beginning of the Twenty First Century in P.S. Okoth, Editor, Africa at the Beginning of the $21^{\text {st }}$ Century_(Nairobi, Nairobi University Press, 2000), pp. 367-389

${ }^{105}$ Omar Kabraj The Challenge of Africa Development (Oxford, Oxford University Press, 2003) pp1-23

${ }^{106}$ George B.N Agiffey Africa Unchanged: The Blueprint for Africa's Future (New York, Palgrave McMillan, 2005), pp.57-93
} 
E.S. Otieno Odhiambo "Africas Place in World Dialogue at the Beginning at the TwentyFirst Century "G.P Okoth Africa at the Beginning of the $21^{\text {st }}$ Century (Nairobi, Nairobi University Press, 2000), pp.213-227

ECA 1996, Africa in the 1990's and beyond: ECA-Revised long term development Perspectives Study (ECA/SERPD/TP/96/3), Addis Ababa.

ECA 1996, Measures to Consolidate Privatization in the African Industrial Sector with Special Emphasis on the Programme of the Second Industrial Development Decade for Africa (ECA/IHSD/IPPIS/003/96), Addis Ababa

ECA/UNIDO, 1995, Report on regional strategy for Rational Location of Industries in the Context of the Abuja Treaty (CAMI.12/), Addis Ababa.

Eric Masinde Aseba Africa in the $21^{\text {st }}$ Century (Eldoret, Zapf Chancery, 1996), pp.29-37

Fanta Cheru African Renaisance: Roadmaps to The Challenge of Globalization (London, Zed Books 2002), pp. 1-32

George B.N Agiffey Africa Unchanged: The Blueprint for Africa's Future_(New York, Palgrave McMillan, 2005), pp.57-93

Gordon Cumming Aid to Africa: French and British Policies from the Cold War to the New Millenium_(London, Ashgate, 2001).

Gromyko, Anatoly A., Editor, 1990, "Development of food production and distribution in the Agrarian Sector." Agenda for Action: African-Soviet - Cooperation, Lynne Reinner Publishers, London.

Harris, Nigel , 1986, The End of the Third World, I.B. Tauris and Co. Ltd., Bungay, U.K. Henning Nelber et al The Partnership for Africa's Development (NEPAD) -Africa Perspectives_(Uppsala, Nordiska Afrika Institutet, 2002), pp 1-33.

Ian Jaylor and Paul Williams (Editor) Africa in International Politics: External Involvement in the Continent_(London, Roundledge, 2004), pp 174-194

J.C.N Osogo Kenya's World of Commerce and Industry (Nairobi 1970), pp.17-27

James Shilwat (Editor) Reclaiming Africa (Nairobi, The Inter Region Economic Network IREN 2004)

John Radey Understanding Development: Theory and Practice in the Third World (University, College London, 1997), pp27-53

Juo. Anthony S.R and Freed Russell D., editor, 1995, Agriculture and the Environment: Bridging food production and environmental protection in Developing countries, ASA Special publication Number 60, Madison.

Khennas, Smail ed., 1992 Industrialization, Mineral Resource and Energy in Africa, CODESRIA, CODESRIA Book Series, Rowe, Oxford.

Maurice N. Amutabs "Globalisation and the Politics of GNS and GOP in Twenty-First Century Africa: ACritical Reflection; in P.G. Okoth Africa at the Beginning of the $21^{\text {st }}$ Century (Nairobi, Nairobi University Press) pp, 269-286

Meier. Gerald M. and William F. Steel, eds., 1989, Industrial Adjustment in sub-Saharan Africa, EDI series in Economic Development, Published for the World Bank, Oxford University Press, New York.

Michael Braff Brown Africa Choices: After Thirty Years of the World Bank (Boulder, West view Press, 1995), PP.1-13, PP13-29, PP 29-50 PP 50-65 PP 65-83 PP83-100 pp 135-154.

Michal P.Todaro Economic Development in the Third World (London, Longman, 1989), 62-85 
Musa I.M Abutundu "Reflections on Early 21 st Century Africa "In Olugbenga Adesida and Annual Otch (Editor) Africa Volces and African Visitors (Stockholm, Elanders Gotab, 2004), pp. 19-30

OAU. 1981, Lagos Plan of Action for the Development of Africa, International Institute for Labour Studies. Geneva.

Omar Kabraj The Challenge of Africa Development (Oxford, Oxford University Press, 2003) pp1-23

P.Ndegwa, L.P Mureithi and R.H. Green Development_Options for Africa: In the 1980s and Beyond_(Nairobi, Oxford University Press, 1985) pp. 17-27

P.S Okoth "The changing Realities of Africa at the Beginning of the Twenty First Century in P.S. Okoth, Editor, Africa at the Beginning of the 21 ${ }^{\text {st }}$ Century_(Nairobi, Nairobi University Press, 2000), pp. 367-389.

Peter Angang' Nyango "The Posibilities and Historical Limitations of ImportSubstitution Industrialization Kenya" In Peter Coughli and Gernshon Ikiara Industrialization in Kenya: In Search of a Strategy_(London, James Canney 1998), pp 651

Peter Sehweb Africa: A continent self-Destruct_(New York, Palquave, 2001).

PumaC.Samanta "What Helps or Hurts Industrialization: A Review from Economic History" in, Purna Samantra and Raj Kumar Sen Realizing African Development: A Millennial Analysis (CIIDS and IIDS, 2001), pp. 84-103

R. B. Sutcliffe Industry and Underdevelopment_(Massachusetts Addison - Wesley Publishing Company 1971), pp. 16-103

Reich, Robert B., 1991 The Work of Nations, Simon \& Schuster, London.

Riddel, Roger C., 1990, Manufacturing Africa, Heinmann Educational Books Inc., Portsmouth.

Roger Fiddel etal Manufacturing Africa: Performance and Prospects of Seven hunter in Sub-Saharan Africa_(Portsmouth Heinemann, 1990, pp. 10-58

Roy Cole and H.J De Blij A Survey of Sub-Saharan Africa_(New York Oxford University Press, 2007)

S.K.B Asante African Development: Adebayo Adedoji's Alternative Strategies (Melboume Hans Zell Publishers_1991) pp.36-78

Singer, Hans, 1977, Technologies for Basic s Needs, ILO, Geneva.

Sola Ankrinade and Amadu sesuy (Editor) Africa in the Post-Cold War International System_(Washington Printer, 1998),pp. 3- 28

Stephen Fellis (Editor) Africa Now: People, Policies and Institutions London, James Carrey, 1996),pp155-174

T.J. Mboya "The Challenge of Development in Contemporary African Monographs, The Challenge Development (East Africa Foundation Publishers, 1968), pp .27-41

Timothy Muriithi The African Union : Pan-Africanism Peace Building and Development ( Burlington, Ashgate Publishing Coupary, 2005), pp. 137-169

UN, 1995, World Economic and Social Survey 1995: Current Trends and Policies in the World Economy, (E/1995/50), New York.

UN,1982, A Programme for the Industrial Development Decade for Africa, New York. UNCTAD African Development in a Comparative Perspective (Oxford, Janexs Currey, 1999)

UNDP, 1996, Human Development Report 1993, Oxford University Press, New York. 
UNDP, 1996, Human Development Report 1996, Oxford University Press, New York. UNIDO Industrial Development Report_(UNIDO, Global Report 1996).

UNIDO, 1975, Lima Declaration and Plan of Action on Industrial Development and Cooperation, Vienna.

UNIDO, 1979, No. 1, Conceptual and Policy Framework for Appropriate Industrial Technology, Monographs on Appropriate Industrial Technology UN, New York.

UNIDO/ECA, 1997, Alliance for Africa's Industrialization, Thirteenth Meeting of the Conference of African Ministers of Industry (CAMI.13/5),Accra.

United Nations Economic Commission for Africa Transforming Africa's Economics (Addis Ababa UNCA, 2001), pp. 18-28)

V.A Oyenga "Industrial Versus Agricultural Development in Africa, in Contemporary Africa Monographs The challenge of development (E.A.E.P, 1968), pp.93-106

Vijay Gupta Africa: Post Cold War Era (New Delhi, Har-Anand Publications, 1996), pp. $1-13$

World Bank Can Africa Claim the $21^{\text {st }}$ Century? (Washington DC, World Bank, 2000), PP.210-219

World Bank Sub-Saharan Africa: From crisis to sustainable Growth._ Washington, World Bank, 1989). 